\title{
Pusat Pelatihan E-Sport Mobile dan Personal Computer Bertema Arsitektur Futuristik di Surabaya
}

\author{
Reno Rizky Mahesa ${ }^{1}$, Suci Ramadhani ${ }^{2}$, Sigit Hadi Laksono ${ }^{3}$ \\ Jurusan Arsitektur, Fakultas Teknik Sipil dan Perencanaan, Institut Teknologi Adhi Tama Surabaya \\ Email: ${ }^{1}$ renorizky950@ gmail.com
}

\begin{abstract}
E-Sport which belongs to global phenomenon was derived from a competition held by a community. E-Sport that stands for electronic sport is a sport using game as the main competitive field played by professionals. Some years ago, E-Sport was not widely known in Surabaya even Indonesia. Nowadays, the phenomenon of E-Sport keeps growing and triggers attention from various parties. This sort of sport is not only playing the game but also spending the time, as being interpreted by many people so far. Basically, E-Sport is similar to other mental and mind sports like chess which has been categorized as a sport and contended in the Olympiad. In the E-Sport industry, to be an expert in playing game, someone must do exercises regularly and improve his ability. However, exercises in the game video do not mean just play much, frequently, and as long as possible. Therefore, this project designed E-Sport Training Centre exactly to develop a building for E-Sport gamers considering that E-Sport has grown tremendously and become prospective in Indonesia. Whether or not a place can be used as a training centre is not only determined by the computer speed but also other things that support the gamers, such as conducive rooms and available facilities for physical exercises of gamers.
\end{abstract}

Keywords: E-Sport, Game, sports, play, training

\begin{abstract}
Abstrak. E-Sport yang kini menjadi fenomena global, bermula dari sebuah kompetisi yang diadakan oleh suatu komunitas. E-Sport sendiri adalah kependekan dari electronic sport, yaitu olahraga yang menggunakan game sebagai bidang kompetitif utama yang dimainkan oleh profesional. Beberapa waktu lalu, E-Sport tidak dikenal di Surabaya maupun Indonesia. Namun sekarang seiring waktu fenomena E-Sport terus berkembang dan mulai memancing perhatian dari berbagai kalangan. E-Sport bukan sekedar bermain game untuk mengisi waktu, seperti yang dipersepsikan selama ini. E-Sport sama halnya dengan olahraga mental dan pikiran lainnya, seperti catur yang sudah termasuk dalam kategori olahraga dan diperlombakan pada olimpiade. Untuk bisa menjadi lebih lihai dalam bermain game dalam industri E-Sport, seorang pemain harus sering melakukan latihan dan meningkatkan kemampuannya. Namun latihan dalam video game bukan berarti sekedar bermain sebanyak, sesering, dan selama mungkin. Karena itu, Proyek ini akan merancang pusat pelatihan E-Sport. Karena diperlukan sebagai wadah bagi para gamer E-Sport, mengingat perkembangan E-Sport saat ini cukup pesat dan menjanjikan di Indonesia. Untuk menentukan suatu tempat bisa jadi pelatihan itu bukan hanya didasari computer yang dipakai kencang. Melainkan ada hal lain yang menunjang para gamer seperti ruang yang begitu nyaman untuk aktifitas bermain game dan memiliki berbagai fasilitas untuk latihan fisik para gamer.
\end{abstract}

Kata Kunci: E-Sport, Game, olahraga, pelatihan 


\section{Pendahuluan}

Kota Surabaya adalah kota Provinsi Jawa Timur. Surabaya merupakan kota terbesar yang berarti Kota Surabaya merupakan pusat bisnis, perdagangan, industri dan Pendidikan di Jawa Timur. Sebagai pusat Pendidikan, penduduk Surabaya juga memiliki persentase yang banyak untuk kalangan remaja dari berbagai daerah seluruh Indonesia.

Meskipun Surabaya keaslian budayanya masih tetap hidup dan berkembang sampai saat ini, tetapi perkembangan teknologi tidak bisa dihindari dari berjalannya di zaman modern ini. Seiring perubahan zaman dan teknologi, perkembangan industri game di Surabaya ternyata bisnis dengan nilai yang cukup luar biasa.

Aktivitas bermain game sudah bertranformasi menjadi olahraga elektronik bertajuk $E$ Sport. Di Indonesia, gaming resmi menjadi cabang olahraga, ditandai dengan berdirinya Indonesia E-Sport Association tahun 2014. Olahraga ini belum sepopuler cabang olahraga lain di Indonesia, namun perkembangannya cukup pesat. Secara umum, E-Sport masih membutuhkan pengelolaan yang professional. Selanjutnya, urusan infrastruktur akan mengikuti, seperti pengadaan stadion khusus gaming dengan perlengkapan E-Sport yang memadai.

Salah satu tantangan terbesar perkembangan E-Sport di Surabaya adalah perbedaan pandangan antara generasi milenial dan generasi senior yang masih dinilai buruk suatu game mobile maupun Personal Computer. Karena E-Sport bukan sekedar bermain game untuk mengisi waktu, seperti yang dipersepsikan selama ini.

Proyek ini akan dirancang pusat pelatihan E-Sport. Langkah ini dilakukan sebagai wadah bagi para gamer E-Sport, mengingat perkembangan E-Sport saat ini cukup pesat dan menjanjikan di Indonesia. Untuk menentukan suatu tempat bisa jadi pelatihan itu bukan hanya didasari komputer yang dipakai kencang. Melainkan ada hal lain yang menunjang para gamer seperti ruang sportif dan sesuai stadart professional untuk para gamer.

\section{Tinjauan Pustaka}

Pusat pelatihan termasuk salah satu wujud dari public space. Laksono (2018) mengungkapkan bahwa dalam mendesain suatu bangunan dengan fungsi public space harus berdasarkan konteks yang ada. Hak itu dikarenakan tiap desain publis space adalah suatu pengekspresian dari budaya, perilaku, kebiasaan, kebutuhan, sejarah, dan psikologi dari komunitas yang diwadahinya.

Pengertian Futuristik menurut The American \& Heritage dictionaries, futuristic (scribd.com, 2018) adalah : (1) Kepercayaan bahwa tujuan kehidupan dan keinginan seseorang terletak di masa depan bukan pada masa sekarang atau masa lalu. (2) pergerakan artistik yang berasal dari Italia disekitar tahun 1910 dengan tujuan menepresikan energi, dinamisa dan kualitas dari kehidupan kontemporari.

Sedangkan menurut Haryadi, dkk (2015) Futuristik mempunyai arti yang bersifat mengarah atau menuju masa depan. Citra futuristik pada bangunan berarti citra yang mengesankan bahwa bangunan itu berorientasi ke masa depan atau citra bahwa bangunan itu selalu mengikuti perkembangan jaman yang ditunjukkan melalui ekspresi bangunan. Futuristik juga sebagai core values yang mengandung nilai-nilai yaitu; dinamis, estetis dan inovatif terutama dari segi teknologi yang dipakai (canggih), dan ramah lingkungan dengan mengadopsi bentuk-bentuk bebas yang tidak terikat oleh bentuk-bentuk tertentu. Kapabilitas dan fleksibilitas bangunan adalah salah satu aspek dalam futuristik bangunan. Kapabilitas dan fleksibilitas sendiri diartikan sebagai kemampuan bangunan untuk menyesuaikan dan mengikuti perkembangan tuntutan dan persyaratan pada bangunan itu sendiri. Sedangkan kemampuan untuk menyesuaikan dan mengikuti perkembangan jaman hanya bisa diwujudkan atau diimplementasikan dalam penampilan dan ungkapan fisik bangunan. Jadi arsitektur futuristik adalah seni atau gaya bangunan 
dalam perencanaan dan perancangan yang tidak berdasarkan suatu yang terkait dengan masa lalu, tetapi mencoba menggambarkan masa depan dengan bentuk yang mengejutkan.

Dengan melihat pengerian futuristik yang ada, maka diambil kesimpulan pedoman dalm perencanaan berdasarkan ungkapan futuristik, yaitu: (a) Mempunyai konsep masa depan terutama sesuai dengan paradigma perkembangan arsitektur. (b) Bentuk yang didapat bukan bentuk-bentuk tertentu saja, tetapi bentuk bebas yang dekonstruksi. (c) Memanfaatkan kemajuan di era teknologi melalui struktur dan konstruksi menggunakan strutur yang dekonstruksi. (d) Memakai bahan-bahan pre-fabrikasi dan bahanbahan baru, seperti kaca baja aluminium, dll. (e) Memunculkan bentuk-bentuk baru dari arsitektur yang analog dengan musim, maksudnya adalah bentuk yang tidak bisa diduga sebelumnya, dinamis sebagai konsekuensi dari perubahan.

Pengertian E-Sport mengacu pada permainan game elektronik yang bersifat kompetitif. Kata $E$ Sports singkatan dari electronic sports, yaitu olahraga yang menggunakan game elektronik sebagai bidang kompetitif utama yang dimainkan secara profesional. Dengan kata lain, E-Sports adalah olahraga profesional yang dilakukan melalui media elektronik seperti komputer, konsol, handphone, dan sebagainya, yang dilakukan secara profesional.

E-Sport dianggap mulai berkembang setelah ada sebuah kompetisi yang diadakan oleh suatu komunitas penggemar video game sekitar tahun 1972, di Universitas Stanford. Peminat video game pada saat itu masih sedikit dan komputer masih jarang ditemui, sedangkan pada jaman itu belum ada jaringan internet seperti saat ini. Saat teknologi internet mulai merebak di Amerika Serikat pada tahuan 90-an, kompetisi game ini pun berkembang secara online. Selain itu, dengan semakin maraknya kompetisi game online maka bermunculan organisasi yang menjadikan games sebagai sebuah industri yaitu industri $E$ Sport dengan mempertandingkan game yang mulai beragam dan menantang seperti Counter Strike, Warcraft, Quake, dan lain-lain.

Pada dasarnya E-Sport dan Gaming itu sama yaitu tentang games (permainan), namun keduanya memiliki perbedaan yang signifikan yaitu gaming itu rekreasi dan E-Sports itu profesi. Umumnya, gaming atau bermain game dilakukan orang untuk mengisi waktu luang, refreshing atau sekedar hobi saja. Sedangkan E-Sport untuk tujuan profesional atau dipakai buat profesi, kerjanya memang bermain game. E-Sports mirip dengan catur atau brigde (kartu) dimana permainan ini bisa sebagai pengisi waktu luang atau menjadi profesi (atlit).

\section{Metode Penelitian}

Jenis penelitian yang digunakan adalah penelitian deskriptif, penelitian ini berkaitan dengan pengumpulan data untuk memberikan gambaran tentang suatu gejala, umumnya dilakukan dengan metode survey, wawancara, pengamatan, studi kasus, studi korelasi, dan sebagainya. Dengan pengumpulan data untuk memberikan gambaran tentang suatu gejala. Adapun teknik metode yang dipakai untuk mendukung dalam memperoleh data adalah : (1) Metode Interview. (2) Metode Literatur. (3) Metode Dokumentasi. 


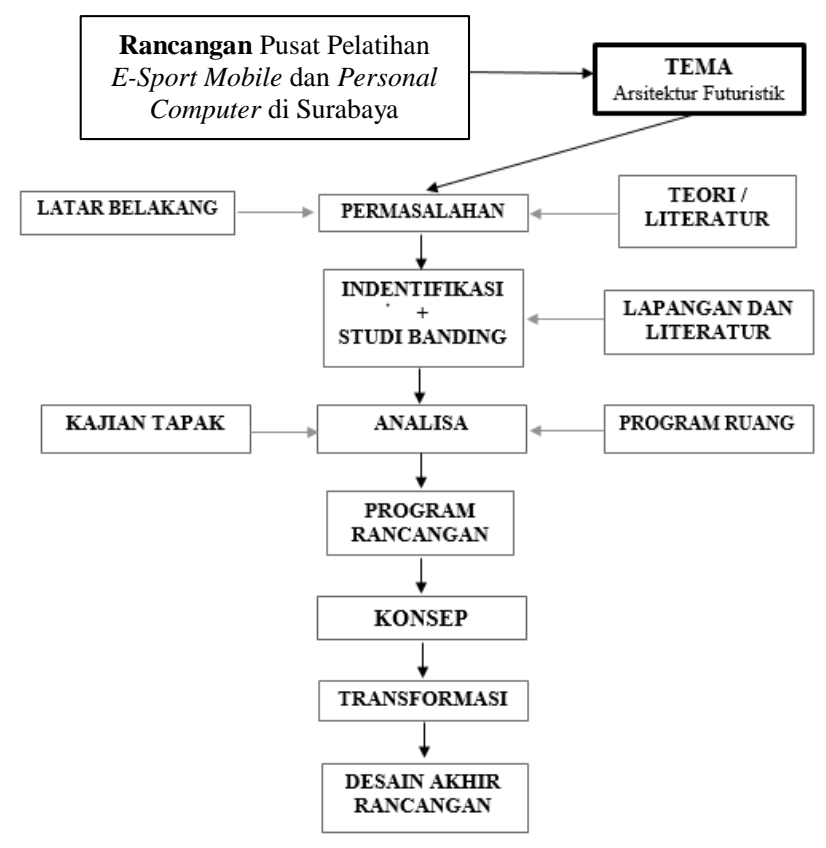

Diagram 1 : Diagram Alur Metodologi

\section{Pembahasan}

Studi kasus lapangan merupakan kegiatan pengumpulan data dengan cara langsung turun ke lapangan dengan mempergunakan Teknik pengumpulan data untuk melengkapi laporan konsep ini yang diantaranya yaitu, wawancara, observasi, dan dokumentasi. Sebagai usaha mencari referensi yang relevan dengan kasus yang disusun pada karya ilmiah. Pengumpulan data pada studi kasus literatur didapatkan dengan mencari data pada text book, jurnal ilmiah, dan melalui media internet. Obyek-obyek studi kasus lapangan tersebut akan dikaji yaitu Universitas Dian Nuswantoro, Semarang dan Gunzie E-Sports arena, Surabaya. Studi kasus literatur The Alienware Training Facility dan E-Sport Training Facility of Chinese Team OMG.

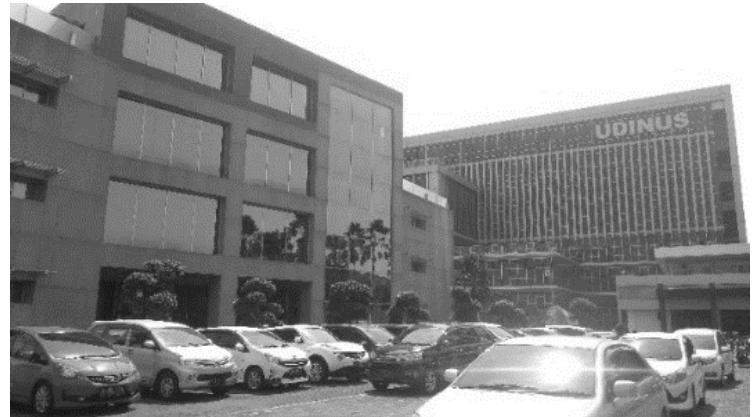

(a)

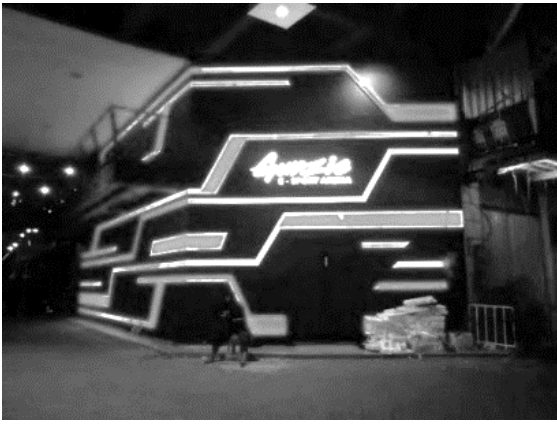

(b)

Gambar 1: Studi kasus lapangan a.), UDINUS, b.) Gunzie E-Sports Arena 


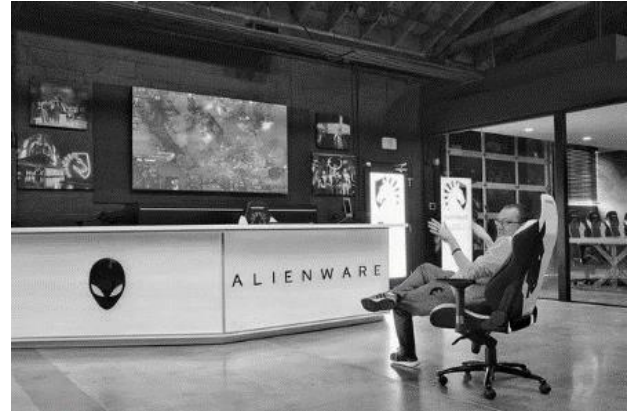

(a)

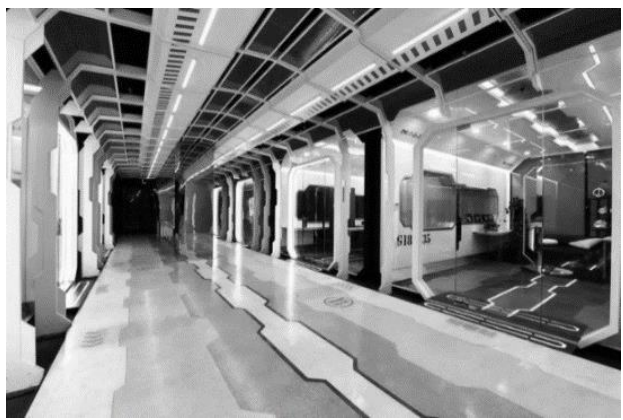

(b)

Gambar 2: Studi kasus literatur a.) The Alienware Training Facility; b.) E-Sport Training Facility of Chinese Team OMG

Sumber : a.) https://www.teamliquid.com/AlienwareTF/, b.) https://ggwp.id/media/2018/08/03/fasilitas-latihan-tim-esports-omg/

Setelah mengkaji studi lapangan maupun studi literatur, dapat disimpulkan bahwa terdapat beberapa kelebihan dan kekurangan dalam kebutuhan ruang tersebut sehingga dapat menjadi contoh dalam merancang Pusat Pelatiahan E-Sport Mobile dan Personal Computer di Surabaya agar menghasilkan rancangan sesuai dengan fasilitas maupun kenyamanan yang lebih baik.

Rangkuman seluruh hasil studi banding lapangan dan literatur : (1) Memprioritaskan pemanfaatan bentuk, ruang yang ada untuk memaksimalkan fungsi dan fasilitas sebagai pusat pelatihan E-Sport. (2) Membangun sarana dan prasarana yang dibutuhkan dalam kebutuhan $E$ Sport dalam aspek pelatihan yang layak digunakan sesuai standar bagi E-Sport. (3) Memanfaatkan material lokal dengan bentuk bangunan yang mampu beradaptasi dengan kondisi lingkungan. (4) Memaksimalkan kenyamanan ruangan sebagai wadah pelatihan yang mampu dimanfaatkan sebaik baiknya.

Tema

Pemilihan desain bangunan bertema futuristik yang menggambarkan suatu bangunan berteknologi canggih karena berkaitan dengan fungsi pada bangunan yang mengutamakan teknologi computer. Dengan tema "Arsiterktur Futuristik" yang dapat memenuhi kebutuhan gamer dari segi kenyamanan, keamanan, serta dapat memenuhi psikologis gamer, lalu ditransformasikan pada perencanaan konsep :

\section{Makro Konsep "Arsitektur Kontemporer"}

Menurut Konnemann, (World of Contemporary Architectur) "arsitektur Kontemporer adalah gaya arsitektur yang bertujuan untuk memberikan contoh suatu kualitas tertentu terutama dari segi kemajuan teknologi dan juga kebebasan dalam mengekspresikan suatu gaya arsitektur."

Gaya ini memicu untuk merancang dan membangun hal-hal yang berbeda dari yang dilakukan di masa lalu dan hal yang biasa dilakukan masa sekarang. Kontemporer juga memiliki kecenderungan untuk berevolusi atau berkembang menjadi sesuatu yang baru.

\section{Mikro Konsep Bentuk "Futuristik"}

Bentuk arsitektur ini tidak lagi mempraktekkan pengaturan bentuk sesuai dengan prinsipprinsip yang telah ditetapkan sebelumnya. Arsitektur Futuristik menolak kemungkinan berkaitan dengan arsitektur. Arsitek futuristik dihadapkan dengan persyaratan untuk kehidupan modern yang berarti menhindari arsitektur yang berbasis tradisional.

\section{Mikro Konsep Ruang "High Tech"}


Perancangan dengan menggunakan konsep arsitektur high tech bukan hanya dilihat dari teknologi canggih yang digunakan namun juga memperhatikan fungsi dari tiap elemennya. Karena tujuan utama dari arsitektur high tech adalah penggunaan teknologi untuk mempermudah aktifitas manusia.

\subsection{Program Ruang}

Penggunaan luas standar, merupakan suatu hasil studi yang sudah ada dan digunakan sebagi acuan perhitungan besaran ruang yang memiliki fungsi serupa. Standar tersebut adalah Neufert Architect's Data (NAD), Time Saver Standart (TSS). Selain itu, hasil dari studi lapangan yang telah dilakukan juga digunakan sebagai acuan untuk perhitungan besaran ruang yang memiliki karakteristik kurang spesifik atau belum ditetapkan standarnya.

Pada Pusat Pelatihan E-Sport Mobile dan Personal Computer Bertema Arsitektur Futuristik di Surabaya ini terdapat beberapa ruang yang memiliki fungsi yang berbeda-beda. Berikut jenis-jenis ruang yang disediakan :

(1) Ruang gaming tingkat newbie, normal, profesional, (2) Ruang analisis, (3) Ruang meeting, (4) Ruang kepala pusat, (5) Ruang Pelatih, (6) Ruang marketing, (7) Ruang administrasi.

Game E-Sport yang diterapkan pada pelatihan, antara lain : game Mobile (Mobile Lagend \& PUBG Mobile), game Personal Computer (Dota 2, CS;GO)

Tabel 1: besaran ruang fasilitas pelatihan $E$-Sport

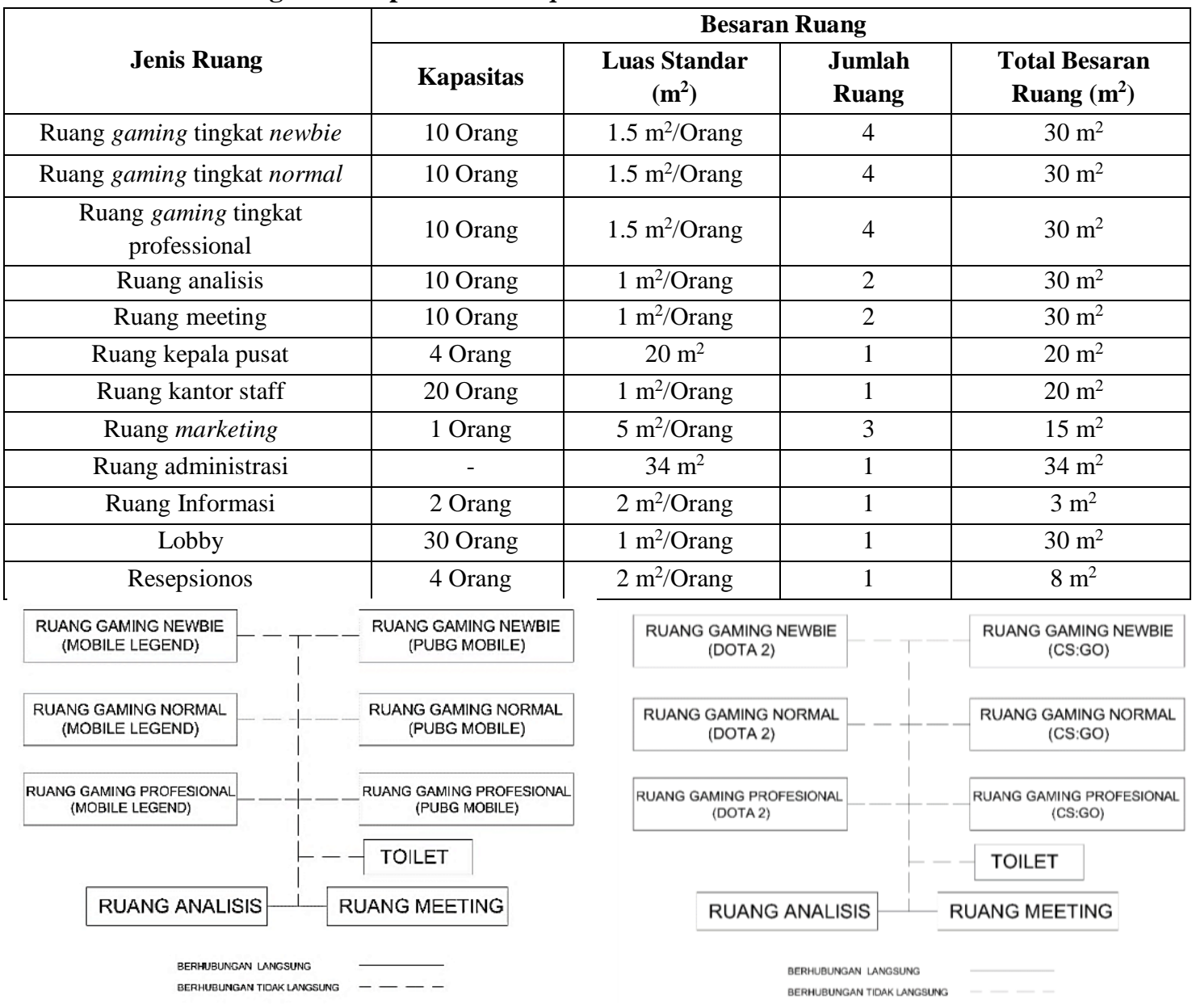




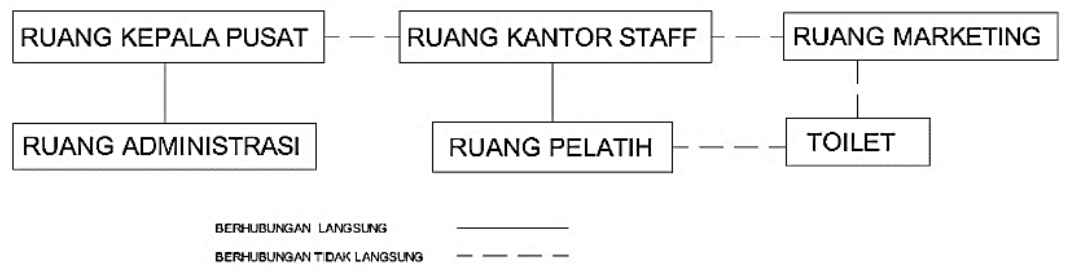

Gambar 4: Organisasi ruang pelatihan E-Sport

\subsection{Transformasi Bentuk}

Tema arsitektur futuristik menggambarkan suatu teknologi dimana semakin majunya perkembangan teknologi yang diciptakan manusia. Futuristik merupakan suatu paham kebebasan dalam mengungkapkan atau mengekspresikan ide atau gagasan ke dalam suatu bentuk tampilan yang tidak biasa, kreatif dan inovatif. Hasil dari futuristik ini adalah sesuatu yang dinamis.

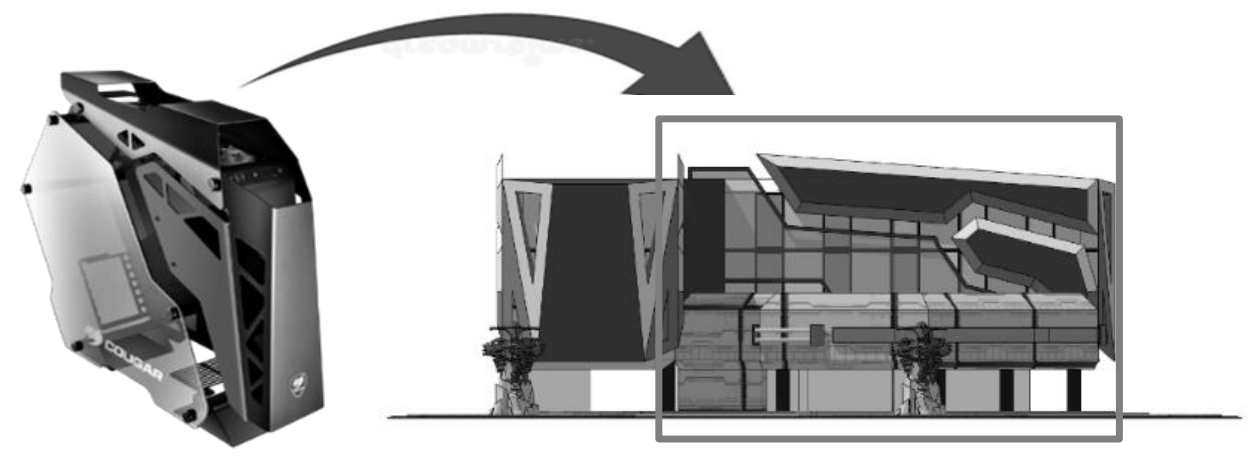

Gambar 3: Transformasi bentuk

\subsection{Transformasi Ruang}

Menciptakan desain ruang yang berhubungan dengan teknologi masa depan. Arsitektur high tech muncul sebagai pengubahan paham sebelumnya yang ditunjang oleh kemajuankemajuan dalam teknologi. Kemajuan ini memicu pola pikir manusia untuk berpikir bahwa banyak yang dapat dicapai dengan kemajuan teknologi. Dalam penerapannya, pengembangan kecanggihan teknologi dan menggunakan elemen-elemen struktural yang sangat dominan dengan material pabrikasi pada elemen interior.
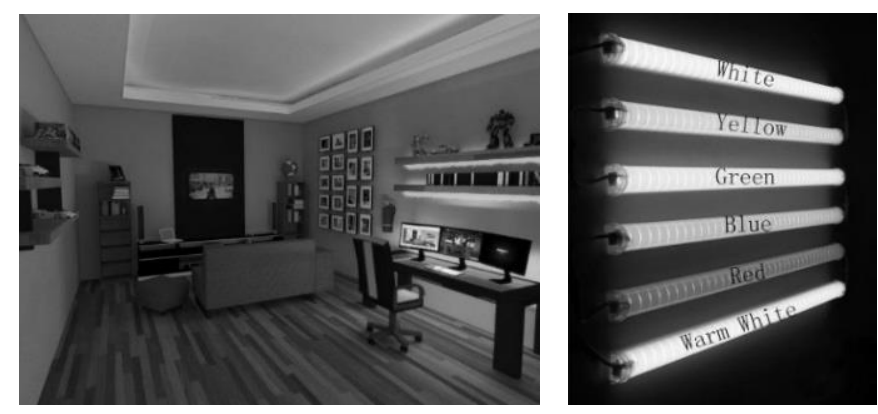

Gambar 4: Transformasi ruang

\subsection{Desain Bentuk}

Penggunaan secondary skin dengan material ACP yang sebagai ciri khas pada bangunan yang menyerupai CPU yang menggambarkan mesin utama pada komputer dengan penambahan lampu LED yang berwarna merah dan biru sehingga terkesan contras dengan warna bangunan. 


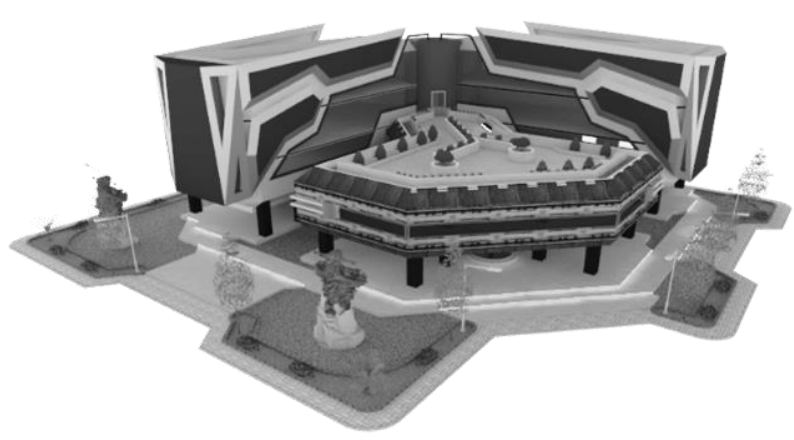

Gambar 5: Bentuk Pusat Pelatihan E-Sport

\subsection{Desain Ruang}

Fasilitas yang memerlukan teknologi dengan konsep high tech, menciptakan desain ruang yang berhubungan dengan teknologi masa depan, untuk itu penamabahan lampu LED berwana mencolok pada ruang yang memiliki bentuk garis-garis pada dinding yang menyatukan pada teknologi-teknologi pada ruangan.

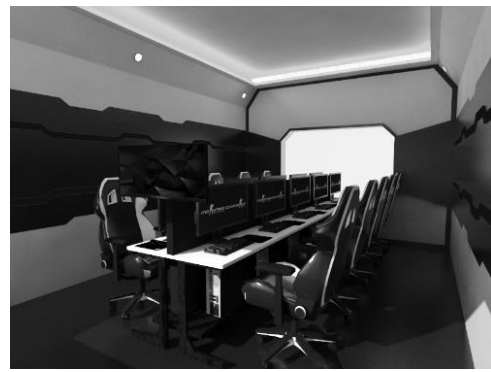

(a)

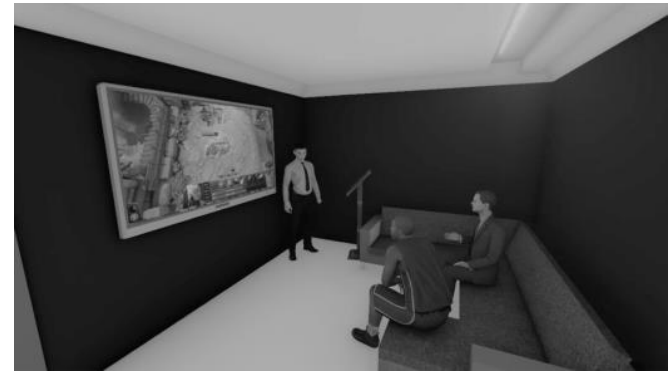

(b)

Gambar 6: a) Ruang Pusat Pelatihan E-Sport, b) Ruang Analisis
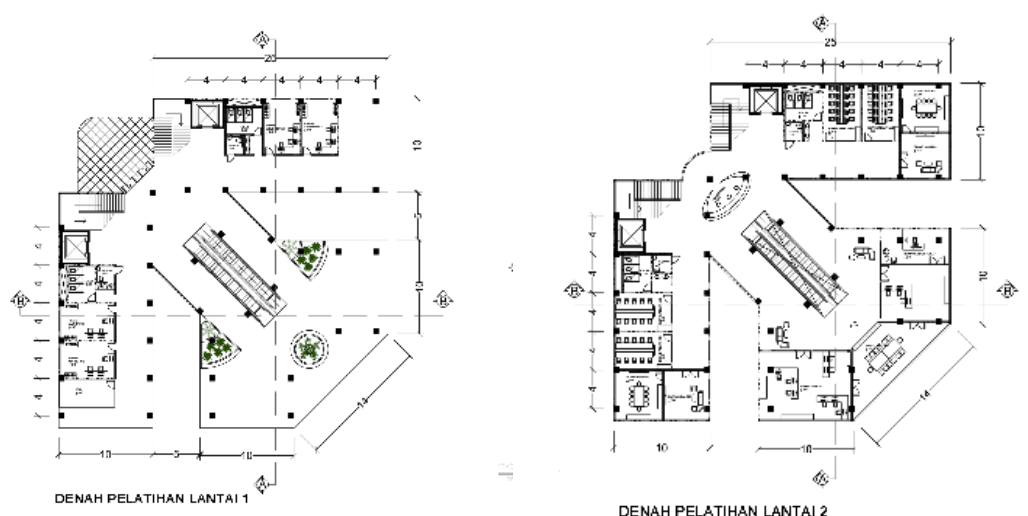

Gambar 7: Denah lantai 1 \& 2

Material Akustik yang digunakan :

Material penyerap (absorber), Material penyerap digunakan di dalam ruangan adanya pengurangan waktu dengung.

Material pemantul (reflector), Panel pemantul digunakan adanya bunyi pantul yang mendukung kualitas akustik di posisi tertentu. Bahan yang digunakan biasanya bersifat licin dan keras sehingga pemantulan specular dapat terjadi. 
Material penyebar (diffuser), Material penyebar bunyi atau diffuser dibutuhkan adanya distribusi bunyi yang merata dengan mempertahankan waktu dengung ruang.

\subsection{Desain Struktur}

System struktur yang perlu diperhatikan seperti pondasi, kolom, balok, dan rangka atap pada bangunan. Maka penerapan bangunan ini menggunakan material beton pada kolom dan pondasi pancang sebagai penumpu pada bangunan ini menjadikan bangunan yang kokoh dan aman untuk berdirinya bangunan dari beban yang diterima.

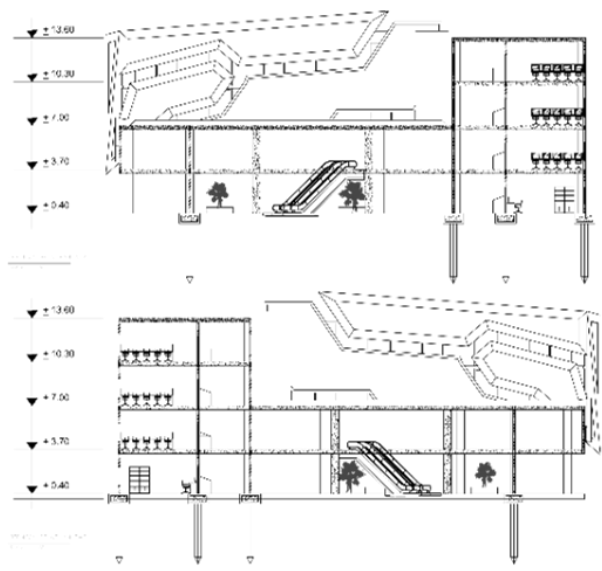

Gambar 8: Potongan Bangunan

\subsection{Desain Lansekap}

Penggunaan tanaman dan pohon ditempatkan pada posisi yang mengelilingi bangunan yang bertujuan terciptanya kenyamanan dan asri. Dikarenakan seringnya aktivitas pada ruang dalam, penambahan ruang terbuka hijau bertujuan untuk area refreshing bagi pemain $E$-Sport.

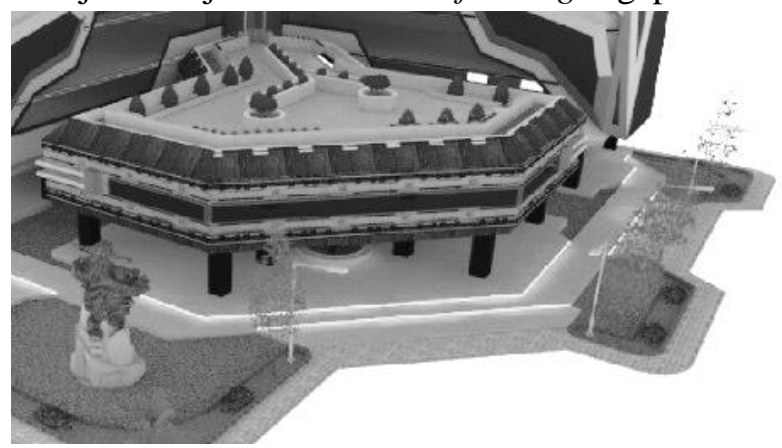

Gambar 9: Desain lansekap

\section{Kesimpulan}

Pusat Pelatihan E-Sport Mobile dan Personal Computer di Surabaya adalah wadah untuk para gamers dengan mempelajari E-Sport, para gamers berkesan mengembangkan potensi dirinya dengan optial. Alasan pemilihan lokasi site untuk mengetahui perkembangan E-Sport di Surabaya dan sebagai bahan masukan bagi masyarakat pada umumnya terkait informasi E-Sport di Surabaya. Pemilihan desain bangunan bertema futuristik yang menggambarkan suatu bangunan berteknologi canggih karena berkaitan dengan fungsi pada bangunan yang mengutamakan teknologi computer. Tujuan dari proyek ini adalah menyediakan sarana dan prasarana bagi para gamers yang berminat untuk menjadi atlet $E$-Sport dengan desain bangunan berbentuk futuristik dan dilengkapi fasilitas yang terpadu sehingga masyarakat tertarik. 
Makro Konsep “Arsitektur Kontemporer", diterapkan sebagai gaya untuk memicu merancang dan membangun hal-hal yang berbeda dari yang dilakukan di masa lalu dan hal yang biasa dilakukan masa sekarang. Kontemporer juga memiliki kecenderungan untuk berevolusi atau berkembang menjadi sesuatu yang baru. Mikro Konsep Bentuk "Futuristik", bentuk arsitektur ini tidak lagi mempraktekkan pengaturan bentuk sesuai dengan prinsip-prinsip yang telah ditetapkan sebelumnya. Arsitektur Futuristik menolak kemungkinan berkaitan dengan arsitektur. Mikro Konsep Ruang "High Tech", menginterpretasikan sebuah sistem teknologi yang digunakan pada suatu bangunan yang mengekspose penggunaan material-material secara transparan.

\section{Referensi}

Haryadi, Syalam, dkk. (2015). Pekanbaru Convention Center dengan Penekanan Bangunan Futuristik. JOM FTEKNIK, 2 (1)

Laksono, S. H. (2018). Site Design of Public Space under the Jenggolo Sidoarjo Flyover, East Java is reviewed from the Location Characteristics. International Journal of Advanced Engineering Research and Science, 5 (12), 268257

Nugroho, Nancy Yusnita, Maurina, Anastasia, Wicaksono, R. Satrio, dan Gani, Vincentius. (2015). Korelasi Bentuk Dinamis dengan Ruang - Struktur - Enclosure pada Bangunan Ciwalk Extention Bandung. RESEARCH REPORT - ENGINEERING SCIENCE, 2.

Pangerang, Syafrian. (2016). Perencanaan Studio Desain Komunikasi Visual dengan Pendekatan Gaya Arsitektur Futuristik di Kendari, Universitas Halu Oleo

Putra, Raden Muhammad Satria. (2014). Perkembangan Esport di Mata Internasional dan Pengakuan Serta Pengaruhnya Terhadap Masyarakat di Indonesia, Universitas Katolik Parahyangan. [Diakses dari http://repository.unpar.ac.id/handle/123456789/5575, 2 Oktober 2019].

Riyadi, Gian Wahyu, Mauliani, Lily, dan Sari, Yeptadian. (2019). Penerapan Arsitektur Modern pada Bangunan Singapore Polytechnic di Tangerang. Jurnal Arsitektur PURWARUPA, 3 (2).

Rofiq, Adrian, Arief, Abdurrachman, dan Siswanto, Ari. (2019). Perancangan Pusat Komunitas E-Sports di Kota Baru, Lampung. Universitas Sriwijaya. 